\title{
Reconciling the science and policy divide: The reality of scaling up antiretroviral therapy in South Africa
}

\begin{tabular}{|c|c|}
\hline \multicolumn{2}{|c|}{$\begin{array}{l}\text { Authors: } \\
\text { Alan Whiteside }{ }^{1,2} \\
\text { Jamie Cohen } \\
\text { Michael Strauss }^{4}\end{array}$} \\
\hline \multicolumn{2}{|c|}{$\begin{array}{l}\text { Affiliations: } \\
\text { 1Balsillie School of } \\
\text { International Affairs, } \\
\text { Waterloo, Canada }\end{array}$} \\
\hline \multicolumn{2}{|c|}{$\begin{array}{l}{ }^{2} \text { College of Law and } \\
\text { Management Studies, } \\
\text { University of KwaZulu-Natal, } \\
\text { South Africa }\end{array}$} \\
\hline \multicolumn{2}{|c|}{$\begin{array}{l}{ }^{3} \text { Harvard School of Public } \\
\text { Health, Boston, United States }\end{array}$} \\
\hline \multicolumn{2}{|c|}{$\begin{array}{l}{ }^{4} \text { Health Economics and HIV } \\
\text { and AIDS Research Division, } \\
\text { University of KwaZulu-Natal, } \\
\text { South Africa }\end{array}$} \\
\hline \multicolumn{2}{|c|}{$\begin{array}{l}\text { Correspondence to: } \\
\text { Michael Strauss }\end{array}$} \\
\hline \multicolumn{2}{|c|}{$\begin{array}{l}\text { Email: } \\
\text { straussm@ukzn.ac.za }\end{array}$} \\
\hline \multicolumn{2}{|c|}{$\begin{array}{l}\text { Postal address: } \\
\text { Private Bag X54001, Durban } \\
4000 \text {, South Africa }\end{array}$} \\
\hline \multicolumn{2}{|c|}{$\begin{array}{l}\text { Dates: } \\
\text { Received: } 27 \text { Jan. } 2015 \\
\text { Accepted: } 13 \text { May } 2015 \\
\text { Published: } 02 \text { July } 2015\end{array}$} \\
\hline \multicolumn{2}{|c|}{$\begin{array}{l}\text { How to cite this article: } \\
\text { Whiteside A, Cohen J, Strauss } \\
\text { M. Reconciling the science } \\
\text { and policy divide: The reality } \\
\text { of scaling up antiretroviral } \\
\text { therapy in South Africa. S } \\
\text { Afr J HIV Med. 2015;16(1), } \\
\text { Art. \#355, } 5 \text { pages. http:// } \\
\text { dx.doi.org/10.4102/ } \\
\text { sajhivmed.v16i1.355 }\end{array}$} \\
\hline \multicolumn{2}{|c|}{$\begin{array}{l}\text { Copyright: } \\
\text { (C) 2015. The Authors. } \\
\text { Licensee: AOSIS } \\
\text { OpenJournals. This work is } \\
\text { licensed under the Creative } \\
\text { Commons Attribution } \\
\text { License. }\end{array}$} \\
\hline \multicolumn{2}{|l|}{ Read online: } \\
\hline 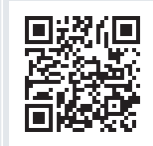 & $\begin{array}{l}\text { Scan this QR } \\
\text { code with your } \\
\text { smart phone or } \\
\text { mobile device } \\
\text { to read online. }\end{array}$ \\
\hline
\end{tabular}

With the world's largest national treatment programme and over 340000 incident cases annually, the response to HIV in South Africa is hotly contested and there is sometimes a dissonance between activism, science and policy. Too often, policy, whilst well intentioned, is informed only by epidemiological data. The state of the healthcare system and sociocultural factors drive and shape the epidemic and its response. By analysis of the financial, infrastructural, human resources for health, and governance landscape in South Africa, we assess the feasibility and associated costs of implementing a universal test and treat programme. We situate a universal test and treat strategy within the governance, fiscal, human resources for health, and infrastructural landscape in South Africa. We argue that the response to the epidemic must be forward thinking, progressive and make the most of the benefits from treatment as prevention. However, the logistics of implementing a universal test and treat strategy mean that this option is problematic in the short term. We recommend a health systems strengthening HIV treatment and prevention approach that includes scaling up treatment (for treatment and prevention) along with a range of other prevention strategies.

\section{Introduction}

South Africa currently has the world's highest national incidence of HIV and AIDS, with 6.4 million people infected and over 340000 incident cases annually. ${ }^{1}$ The history of the epidemic and the political, economic and policy response has been well documented by academics. ${ }^{2,3,4}$ In brief, the government refused from 1999 to 2004 to provide antiretroviral therapy via public facilities. The then Head of State, Thabo Mbeki, aided and abetted by Minister of Health Manto TshabalalaMsimang, a few members of his cabinet and some of the provincial governments, questioned the causal link between the HI virus and AIDS, the effects of antiretroviral therapy (ART), and the motives of pharmaceutical companies. ${ }^{5}$ Despite this opposition, drugs were made available by progressive provincial governments, health workers and activist organisations. Since those bleak days of AIDS denialism, and increasingly from 2005, ${ }^{5}$ South Africa has expanded its HIV services and today has the world's largest ART programme, reaching about 2.1 million people. ${ }^{1}$

Like most countries in sub-Saharan Africa, South Africa tries to base its health policy on World Health Organization (WHO) recommendations. Their guidelines are based on the best available scientific evidence, but do not always speak to economic and social realities, especially regarding HIV and AIDS. The first WHO HIV treatment guidelines were released in 2002, and updated in 2006, 2010 and 2013. The latest WHO clinical recommendations promote treatment initiation for adults and adolescents $>10$ years old whose CD4 count falls below 500 cells $/ \mathrm{mm}^{3}$ and immediate treatment for persons with active TB disease; hepatitis B virus (HBV) co-infection with severe chronic liver disease; pregnant and breastfeeding women with HIV; and those who are HIVpositive in a serodiscordant partnership. ${ }^{6}$

The South African National Department of Health adopted the 2010 recommendations to start adults on treatment at a CD4 cell count $\leq 350$ cells $/ \mathrm{mm}^{3}$, and in 2015 partially adopted the new guidelines. ${ }^{7}$ The only WHO recommendation not adopted in the new South African ART guidelines is the recommendation to initiate serodiscordant couples regardless of CD4 count; the discussion of whether or not to include this is ongoing. However, the government is hesitant to start all HIV-infected individuals on treatment irrespective of CD4 level.

Historically, WHO recommendations drive policy. In the light of the delayed and discrepant policy change in South Africa, it is worth examining the WHO recommendations and process with careful consideration of context. Whilst scientific evidence provides the foundation for the WHO's guidance on expanded treatment eligibility, scientific literature tends to be produced in a vacuum. Increasing the CD4 threshold has implications that reverberate across sectors: it affects budgets, infrastructure and human resources. 
In the present article, we examine how policy has changed and existing constraints on the South African government. The policy debate has been articulated in the pages of this journal, but it is noteworthy that this is the only place where we have seen these arguments ${ }^{7,8}$ as they are generally seen as politically incorrect and going against international norms.

We argue that policymakers must consider the possibility that a 'one-size-fits-all' approach to treatment may not be the most beneficial for patients' health and adherence to treatment, or the most cost-effective for the national budget. ${ }^{7}$ Decisions to change the CD4 threshold in South Africa are not taken lightly, but we are not convinced that there has been sufficient consideration of the implications regarding capacity, adherence and the health of the population. We argue that the treatment agenda has been set outside the country and to unrealistic levels reflecting a dissonance between activism, science and policy. ${ }^{9}$

The success in translating evidence into practice depends on local context, resources, priorities and data. It is our view that the South African government's position is that it, reluctantly, has to change policy if not practice. This works for a relatively well-off country with a powerful political leadership, reasonable public health system, low (and falling) dependence on donors, and a reasonable public platform for debate. In many other settings, governments and ministries of health may be adversely affected by the decrees from Geneva or global capitals.

The present article identifies two major challenges faced in South Africa. First, modelling studies are being given too much emphasis and should not be used, in isolation, to dictate policy. Second, the issue of when to provide ART is being conflated with treatment-based prevention.

It is important, however, to understand the two pressures for treatment. First, it is seen by some as a 'right' that HIVpositive people should get the best available treatment, without considering the broader health context and the need to make choices. Second is the pressure of treatment as prevention. The seminal HPTN 052 study showed the effectiveness of ART in reducing HIV transmission in discordant heterosexual couples. ${ }^{10}$ This study was a key driver for the WHO to revise its guidelines for ART initiation. ${ }^{11} \mathrm{ART}$ is recommended for HIV-positive, pregnant, breastfeeding women; all children under the age of five; people with TB or hepatitis B; and HIV-positive people with HIV-negative partners. ${ }^{6}$

For clarity, we include working definitions of Universal Access and Universal Test and Treat ART rollout strategies as well as treatment as prevention (TasP) (see panel). Papers ${ }^{12,13,14,15}$ that model the cost-effectiveness of universal test and treat in South Africa, using various inputs and assumptions, yield different results. We include an overview of the findings and conclusions of these studies to show the different predicted outcomes and costs of universal test and treat.
Models are a mixed blessing - they can generate useful costeffectiveness data if they are based on realistic assumptions and up to date biomedical data. However, achieving this often proves to be difficult, especially for long-term analyses, because even small inaccuracies or unforeseen costs may lead to very different results. Meyer-Rath and Over ${ }^{15}$ warn about the shortcomings of ART scale-up models that do not account for the flexibility of costs over time. Their model showed that small-scale inefficiencies could lead to far higher costs in the long run.

Although prevention necessarily results from any treatment programme, ${ }^{16}$ it is important when developing policy not to conflate TasP with universal test and treat. We critique universal test and treat in the context of governance, human resources for health, and infrastructural and fiscal constraints in South Africa. The response to the epidemic must be forward thinking, progressive and to make the most of the benefits from TasP. The logistics of implementing a universal test and treat strategy mean that this option is problematic in the short term. We recommend a health systems strengthening HIV treatment and prevention approach, which includes scaling up treatment (for treatment and prevention) along with a range of other prevention strategies.

\section{Governance}

South Africa's Constitution established three spheres of government-national, provincial, and local. Health policy is developed nationally and adapted to fit provincial needs. Healthcare funding, including that for HIV and AIDS, is allocated to provincial departments of health. This system has created and exacerbated health inequities between provinces. The political, socioeconomic and historical context in the nine provinces varies significantly, which affects service delivery (see Table 1$).{ }^{17}$ We illustrate this point with data from the best and worst provinces: the well-resourced and well-governed Western Cape, and Limpopo which has a largely rural population, fewer human resources per capita and inefficient government.

The health profile in South Africa's nine provinces varies between these two extremes. HIV prevalence ranges from $4.75 \%$ in the Western Cape to $24.7 \%$ in KwaZulu-Natal - nearly double that in Limpopo. The number of annual new HIV infections varies by a factor of $30 .{ }^{18}$ In this context, one-sizefits-all interventions cannot work; the gaps in health service facilities, especially staffing levels, are too great. A blanket universal test and treat strategy would be difficult to apply.

\section{Human resources for health capacity}

Human resources are a significant limitation on the ability to effectively deliver health and HIV services. Progress has been made; the number of public sector doctors increased from 7645 in 2003 to 13614 in 2013, and the number of professional nurses registered with the South African Nursing Council from 96715 to $129015 .{ }^{19}$ The number of 
BOX 1: Definitions and models.

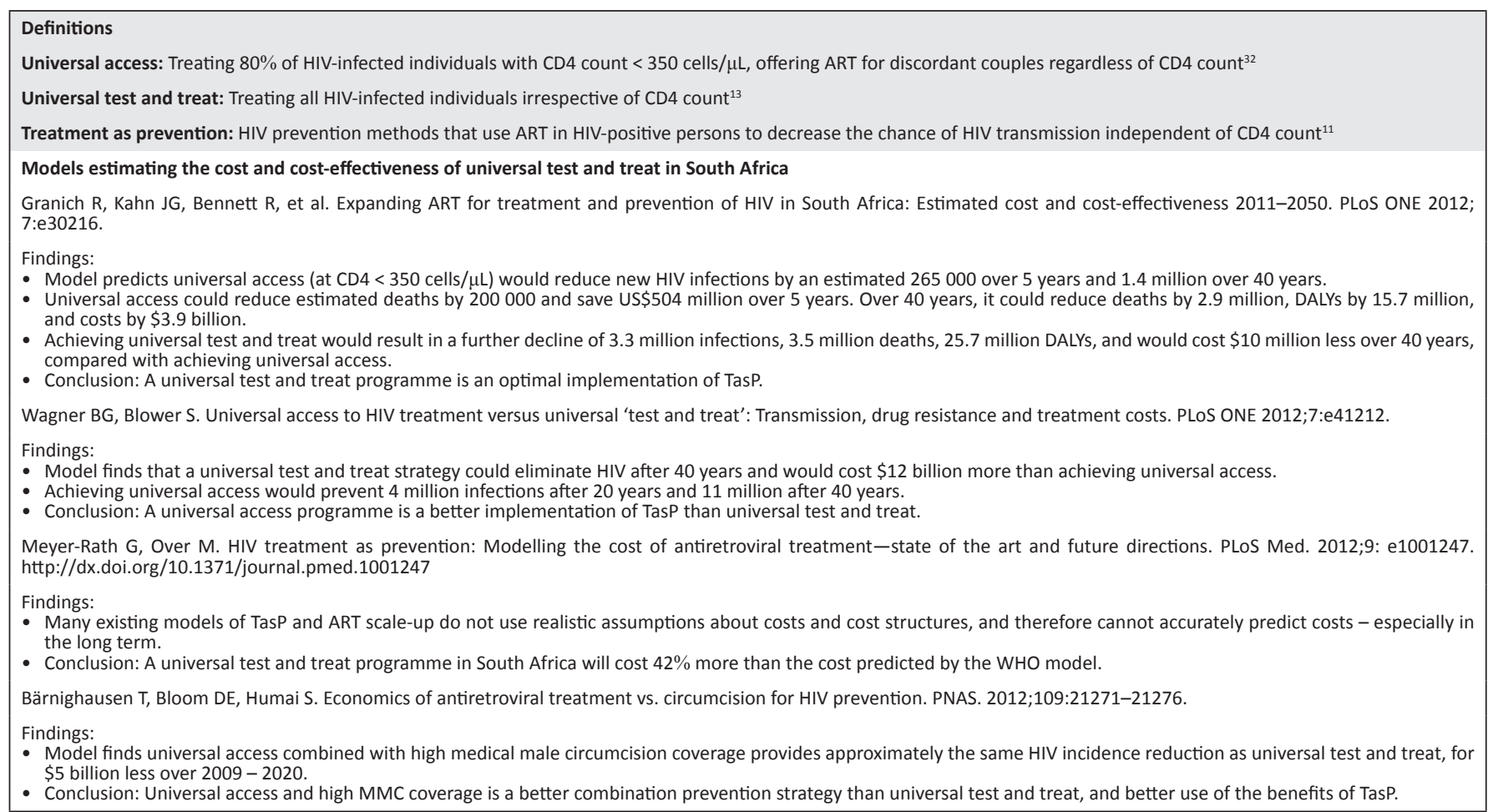

TABLE 1: Provincial inequality.

\begin{tabular}{|c|c|c|}
\hline Indicator & Limpopo & Western Cape \\
\hline Contribution to gross domestic product (2010) & $7.2 \%$ & $14.1 \%$ \\
\hline Percentage of total population & $10.4 \%$ & $11.2 \%$ \\
\hline Percentage of rural population & $90 \%$ & $10 \%$ \\
\hline HIV prevalence (ages 15-49) & $12.92 \%$ & $4.75 \%$ \\
\hline Number of people living with HIV & 409161 & 273114 \\
\hline Number of private hospitals & 8 & 34 \\
\hline Number of public hospitals & 42 & 55 \\
\hline Number of public sector doctors per 100000 population & 20.7 & 34.8 \\
\hline Health professional vacancy rate & $58.5 \%$ & $29.0 \%$ \\
\hline
\end{tabular}

Data compiled from the public domain.

doctors and professional nurses per 100000 people exceeds the WHO minimum.

The problem is the uneven distribution of human resources for health (HRH) across provinces; between urban and rural areas; and between the public and private sectors. ${ }^{19}$ Only $12 \%$ of the country's doctors and $19 \%$ of its nurses work in rural facilities, serving $43.6 \%$ of the population. ${ }^{20}$ These additional strains on an already overstretched health labour force compromise the ability of the health system to provide equal access and increased coverage of treatment and care for people with HIV.

Health facilities face other human resource problems. The real unit costs of labour have almost doubled over the last 15 years. ${ }^{19}$ Put simply, this means that compensation has gone up more than productivity, hence more money has to be spent to achieve the same result. Attrition owing to AIDS and emigration has worsened the ratio of professional and enrolled nurses and doctors to population size in the public sector. There is an historical trend of a substantial proportion of doctors who qualified in South Africa emigrating to work abroad, and many leave the public sector to work in private practice. $^{20}$

Responses include expanding and auditing the quality and relevance of training to meet the demand for health services, task shifting and developing strategies for ensuring an equitably distributed, long-term supply of HRH. Government's training targets may enable South Africa to reach universal ART, if the skewed distribution of HRH is addressed in conjunction with innovative, task shifting measures. Building human resource capacity to meet the needs of a universal test and treat programme will be a significant challenge in South Africa and will need to be an increasing priority as the treatment programme expands.

\section{Infrastructural capacity}

South Africa's healthcare infrastructure has improved since 1994, but regional and sectoral discrepancies persist (Table 1). Fifteen per cent of poor rural households live 
more than one hour away from the closest clinic, and $20 \%$ live more than one hour away from the closest hospital. ${ }^{21}$ The fragility of the health system was clearly illustrated in December 2012 when Médecins Sans Frontières had to step in to supply the Mthatha medical depot with ARVs for $50000 \mathrm{HIV}$-infected patients. An estimated 5494 adults taking ARVs went at least one day without treatment owing to severe drug supply and delivery disruptions. ${ }^{22,23}$ This service delivery crisis was a symptom of long-standing and systemic infrastructural, human resource capacity and financial mismanagement issues, which continue today. ${ }^{24}$

A universal test and treat programme would place strain on a fragile system, possibly particularly compromising rural healthcare where there may be fewer staff members, and also a dependence on urban-based supply chains. South Africa's public health infrastructure must be strengthened to support the demands of universal ART and the proposed National Health Insurance (NHI) plan.

\section{Financial capacity}

A good understanding of South Africa's healthcare spending shows additional constraints. Overall expenditure on public health grew from R16.4 billion in 2008/2009 to over R30 billion in 2013/2014..$^{25}$ A key component of the expanded health budget is the NHI plan, to be phased-in over 14 years. This plan aims to restructure and strengthen the public health system and improve quality of care. The NHI will require significant financial expenditure, imposing a further fiscal burden on taxpayers. NHI-related public spending increased from R119.3 million in 2008/2009 to R491.8 million in $2013 / 2014$, and is expected to increase to R650.1 million by $2016 / 2017 .^{25}$

This expense must be seen against a backdrop of rising HIV spending. Public spending on HIV and AIDS increased from R3.36 billion in 2008/2009 to R10.97 billion in 2013/2014. ${ }^{25}$ Clinical care and treatment support from the President's Emergency Plan for AIDS Relief (PEPFAR), South Africa's largest bilateral donor, will come to an end in 2017, and the focus of this funding is already shifting from treatment to support and technical assistance. The government committed to increase its financing of the National Strategic Plan for HIV, STIs and TB (NSP) from R9.57 billion in 2012 (71\% of NSP) to R15.2 billion in 2017 ( $88 \%$ of NSP). ${ }^{26}$ Despite this outlay, the government is forecasting a widening funding gap; in 2013/2014 it was R2.67 billion. By 2015/2016 the projections are: resource needs of R29.86 billion, government funding of R19.8 billion, and development partners providing R5.02 billion - leaving a gap of over R5 billion. ${ }^{27}$

A universal test and treat strategy does not currently fit into South Africa's available financial resources and spending priorities. Although NHI expenditure will strengthen HIV services, it crowds out the feasibility of investment in a universal test and treat programme unless significant new money is allocated; this could come from re-allocation of national budgets but would require political will.

\section{Treating the region?}

There is evidence of an increasing burden on existing health resources because of 'medical tourists' in South Africa, especially from neighbouring countries. In 2012 there were 6689105 African or Middle Eastern visitors to South Africa, of whom 260875 or $3.9 \%$ were defined as medical tourists. Not all are seeking public health; middle-class visitors may be coming for elective procedures or be covered by insurance; and some regional governments refer (and pay for) patients to attend specialised medical facilities and this is covered under the 1999 Southern African Development Community (SADC) Health Protocol. ${ }^{28}$

There is evidence to show that, as ART coverage improves across the border, so the number of people trying to access treatment in South Africa declines. In the case of Botswana, medical tourists grew from 40000 to just over 50000 between 2003 and 2008. Thereafter, the numbers fell to less than 20000 in 2012. For Mozambique, the number of medical tourists grew rapidly from 8000 in 2003 to about 180000 in 2010. With the expansion of ART coverage in Mozambique, the numbers fell and in 2012 were just less than $100000 .^{28}$ The exception may be Zimbabweans who are primarily in South Africa for employment, and who are accessing ART. Of course, there is also evidence that South Africans are making it difficult for visitors to access treatment in the public sector, and the appalling April 2015 xenophobic attacks sent a message that foreigners are not welcome in the country for any reason. Nevertheless, providing ART to all makes public health sense.

\section{The HIV endgame: An AIDS-free generation}

Significant scientific advances coupled with political will have endowed the world with effective biomedical, behavioural and structural interventions. The conversation is shifting towards a foreseeable end to the epidemic. In the absence of a vaccine or cure, navigating the 'endgame' will be costly and ineffective if plans are designed without context and foresight.

The HIV epidemic in South Africa is driven by deeply entrenched social and structural factors including gender inequality, poverty and migration. ${ }^{29,30}$ Even if the structural inadequacies of the healthcare system are addressed, a one-size-fits-all approach to HIV treatment and prevention will not work. The complexity of the epidemic necessitates a diverse range of interventions which are effective within the South African epidemiological and resource context.

Too often, health policy recommendations are prescribed with good intention but based primarily on modelled outcomes or international 'norms', with little attention paid to local context. Successful programmes that will make a real impact hinge on much more. Fiscal, infrastructural and human resources for health, political and sociocultural 
factors drive and shape the epidemic and should inform its response.

Given these constraints, it is clear that a universal test and treat strategy, and a combination prevention and treatment approach that includes a strengthening of the health system, are mutually exclusive in the short term. A premature move to a one-size-fits-all policy will undermine the importance of other interventions that work. Rolling out a comprehensive treatment and prevention programme for HIV based on evidence for efficacy, cost-effectiveness and country-specific context must become a priority.

Strengthening the health system and increasing capacity for HIV treatment must remain high on the agenda, but a universal test and treat strategy cannot be pursued exclusively or to the detriment of other interventions that work, as we have shown elsewhere that there is the potential for a virtuous cycle to begin but it must be properly planned. ${ }^{31}$

In addition to medical interventions, there must be increased emphasis on gender relations and empowering women, especially young women. There needs to be social change, and it may be that requiring some form of payback for treatment not financial but perhaps in terms of volunteerism - will contribute to this.

\section{Conclusion}

South Africa is achieving significant progress in the form of dramatically lower rates of mother-to-child-transmission, falling new infections in young adults, decreasing HIVrelated mortality, and expanding ART coverage. We cannot risk derailing this momentum with premature policy decisions. Universal access should be the primary goal and, in this context, treatment will necessarily lead to prevention.

\section{Acknowledgements Competing interests}

The authors declare that they have no financial or personal relationships which may have inappropriately influenced them in writing this article.

\section{Authors' contributions}

A.W. (Balsillie School of International Affairs) developed an initial conceptual framework for this article. A.W. and J.C. (Harvard School of Public Health) and M.S. (University of KwaZulu-Natal) participated in conceptual development, literature search, writing and finalising of the article.

\section{References}

1. Shisana O, Rehle T, Simbayi L, et al. South African national HIV prevalence, incidence and behaviour survey, 2012. Cape Town: HSRC Press; 2014.

2. Nattrass N. Mortal combat: AIDS denialism and the struggle for antiretrovirals in South Africa. Durban: University of KwaZulu-Natal Press; 2007.

3. Fourie P, Meyer M. The politics of AIDS denialism: South Africa's failure to respond Farnham: Ashgate; 2010
4. Šehović AB. HIV/AIDS and the South African state: Sovereignty and the responsibility to respond. Farnham: Ashgate; 2014.

5. Nattrass N. The AIDS conspiracy: Science fights back. New York: Columbia University Press; 2012.

6. WHO. March 2014 supplement to the 2013 consolidated guidelines on the use of antiretroviral drugs for treating and preventing HIV infection: Recommendations for a public health approach. Geneva: World Health Organization; 2014.

7. Geffen N, Robinson M, Venter F, Sa FCP, Low M. One size doesn't fit all: Tailoring adult antiretroviral treatment. S Afr J HIV Med. 2014;15:77-78. http://dx.doi org/10.7196/sajhivmed.1095

8. Geffen N. World Health Organization guidelines should not change the CD4 count threshold for antiretroviral therapy initiation. S Afr J HIV Med. 2013;14:6-7. $\mathrm{http} / / / \mathrm{dx}$.doi.org/10.7196/sajhivmed.906

9. Coutsoudis A, Goga A, Desmond C, Barron P, Black V, Coovadia H. Is Option B+ the best choice? Lancet. 2013;381:269-271. http://dx.doi.org/10.1016/S01406736(12)61807-8

10. Cohen MS, Chen YQ, McCauley M, et al. Prevention of HIV-1 infection with early antiretroviral therapy. N Engl J Med. 2011;365:493-505. http://dx.doi. org/10.1056/NEJMoa1105243

11. WHO. Programmatic update: Antiretroviral treatment as prevention (TASP) of HIV and TB. Geneva: World Health Organization; 2012.

12. Granich R, Kahn JG, Bennett R, et al. Expanding ART for treatment and prevention of HIV in South Africa: Estimated cost and cost-effectiveness 2011-2050. PLoS One. 2012;7:e30216. http://dx.doi.org/10.1371/journal.pone.0030216

13. Wagner BG, Blower S. Universal access to HIV treatment versus universal 'test and treat'. PLoS One. 2012;7:e41212. http://dx.doi.org/10.1371/journal.pone.0041212

14. Bärnighausen $T$, Bloom DE, Humair $S$. Economics of antiretroviral treatment vs. circumcision for HIV prevention. Proc Natl Acad Sci USA. 2012;109:21271-21276. http://dx.doi.org/10.1073/pnas.1209017110

15. Meyer-Rath G, Over M. HIV treatment as prevention: Modelling the cost of antiretroviral treatment-state of the art and future directions. PLoS Med. 2012;9:e1001247. http://dx.doi.org/10.1371/journal.pmed.1001247

16. Tanser F, Bärnighausen T, Grapsa E, Zaidi J, Newell M-L. High coverage of ART associated with decline in risk of HIV acquisition in rural KwaZulu-Natal, South Africa. Science. 2013;339:966-971. http://dx.doi.org/10.1126/science.1228160

17. Mayosi BM, Lawn JE, van Niekerk A, Bradshaw D, Abdool Karim SS, Coovadia HM Health in South Africa: Changes and challenges since 2009. Lancet. 2012;380: 2029-2043. http://dx.doi.org/10.1016/S0140-6736(12)61814-5

18. Department of Health. The 2011 national antenatal sentinel HIV \& syphilis prevalence survey in South Africa. Pretoria: National Department of Health; 2012.

19. Health Systems Trust. Health indicators. 2015 [cited 2015 Jan 05]. Available from: http://www.healthlink.org.za/healthstats/index.php?indtype_id =004002

20. George G, Quinlan T, Reardon C, Aguilera J-F. Where are we short and who are we short of? A review of the human resources for health in South Africa. Heal SA Gesondheid. 2012;17:1-7. http://dx.doi.org/10.4102/hsag.v17i1.622

21. Cooke R, Couper I, Versteeg M. Human resources for rural health. In: Padarath $A$, English R, editors. South African Health Review. Durban: Health Systems Trust; 2011; p. 107-118

22. Medecincs Sans Frontieres, Section 27, Rural Health Advocacy Project, Treatment Action Campaign. Emergency intervention at Mthatha Depot: The hidden cost of inaction. 2013 [cited 2013 Feb 05]. Available from: http://www.msf.org.za/ publication/emergency-intervention-mthatha-depot

23. Bateman C. Drug stock-outs: Inept supply-chain management and corruption South Afr Med J. 2013;103:600-602. http://dx.doi.org/10.7196/samj.7332

24. Stop Stock Outs Project. Reported stock outs. 2015 [cited 2015 Jan 21]. Available from: http://stockouts.org/index.html

25. National Treasury. Estimates of national expenditure 2014. 2012 [cited 2015 Jan 15]. Available from: http://www.treasury.gov.za/documents/nationalbudget/2012/ ene/FullENE.pdf

26. PEPFAR. Partnership framework implementation plan in support of South Africa' s national HIV, STI \& TB response between the government of the Republic of South Africa and the government of the United States of America. 2012 [cited 2012 Nov 08]. pp. 1-52. Available from: http://www.pepfar.gov/documents/ organization/196651.pdf

27. South African National AIDS Council. Financing the South African National Strategic Plan for HIV, STIs and TB 2012 - 2016: An analysis of funding, funding gaps and financing considerations. Pretoria: South African National AIDS Council; 2013.

28. Crush J, Chikanda A. South-South medical tourism and the quest for health in Southern Africa. Soc Sci Med. 2014;124:313-320. http://dx.doi.org/10.1016/j. socscimed.2014.06.025

29. Campbell C, Mzaidume Y. How can HIV be prevented in South Africa? A social perspective. BMJ. 2002;324:229-232. http://dx.doi.org/10.1136/bmj.324.7331.229

30. Jewkes RK, Dunkle K, Nduna M, Shai N. Intimate partner violence, relationship power inequity, and incidence of HIV infection in young women in South Africa: A cohort study. Lancet. 2010;376:41-48. http://dx.doi.org/10.1016/S01406736(10)60548-X

31. Whiteside A, Strauss M. The end of AIDS: Possibility or pipe dream? A tale of transitions. African J AIDS Res. 2014;13:101-108. http://dx.doi.org/10.2989/160 85906.2014.927780

32. Meintjes G, Maartens G. Guidelines for antiretroviral therapy in adults. S Afr J HIV Med. 2012;13:36-45. http://dx.doi.org/10.7196/sajhivmed.862 